\title{
THE MODEL OF VERBAL RECONSTRUCTION OF SYMBOLS: ASPECT OF DISADOPTATION OF PERSONALITY
}

\author{
Olena Valeriivna Lisoivan \\ Institute of social and political psychology of NAPS (Ukraine)
}

\begin{abstract}
Verbal reconstruction of symbols is a factor of overcoming of the state of personality disadoptation. One of facilities that helps to form the new semantic structures of consciousness, exposes unrealized internal processes and conflicts is verbal reconstruction of symbols. The article is discusses different approaches to the use of verbal reconstruction of symbols on the basis of work with words and their systematization for application in the process of work with the system of symbols of personality with the aim of overcoming of the state disadoptation. With the help of following model of verbal reconstruction of symbols is investigates personal system of symbols.

KEY WORDS: symbol, verbal reconstruction of symbols, theoretical model, disadoptation of personality.

Anotacija

Verbalinė simbolių rekonstrukcija - tai asmenybės statuso disadaptaciją veikiantis veiksnys. Viena iš galimybių formuoti naujas semantines sąmonès struktūras, atskleidžiančias neigyvendintus vidaus procesus ir konfliktus, yra žodinių simbolių rekonstrukcija. Straipsnyje aptariami ịvairūs požiūriai ị žodinių simbolių rekonstrukcijų vartojimą dirbant su žodžiais ir jų sistematizacija, tai gali būti taikoma asmenybės simbolių sistemos formavimo procese, siekiant ịveikti asmenybės statuso disadaptaciją. Taikant žodinių simbolių rekonstrukcijos modelį tiriama asmeninè simbolių sistema. PAGRINDINIAI ŽODŽIAI: simbolis, verbalinè simbolių rekonstrucija, teorinis modelis, asmenybės disadaptacija.
\end{abstract}

\section{Introduction}

The urgency of solving the problem of creating a theoretical model of the study of verbal reconstruction of the characters is due to the existence of different approaches and the lack of a unified systematized and generalized concepts regarding this process. Among the obstacles on this way there is not only the existence of very different psychological directions, with its own internal set of regulations, use of verbal reconstruction of the characters, but also the availability of different views of psychologists regarding this process.

Research on this subject was associated with concepts of interpretation of the characteristics of verbal reconstruction of the symbols by such scientists as N. Barden (2012), T. Williams (2012), N. Linde (2016), V. Yakovlev (2006), T. Yatsenko (2008) and others. It should be noted that there are no clear criteria and the algorithm of work with the verbal reconstruction of the symbols, since it is revealed 
in different approaches through the application of various methods: the method of association, creation tales, questions and answers, and so on.

The symbol needs to be interpreted and to contain reverse-verbal communication, which is based on the reflection of the artist with the aim of translating symbols on a cognitive level. The importance of verbal reconstruction of the symbol is emphasized by G. Goodman (Lebedeva, 2003, p. 21), when he tells about the need to build speech strategies and the correct selection of words, associations at the time of diagnosis of the picture. M. Bakhtina (Lebedeva, 2003, p. 21). believes that the author of the picture can only be understood through communication.

We can say that so far the use of verbal reconstruction of personal characters is relevant because the properties and ways of functioning of this process and its importance in personality development and methods of its interpretation remain outside of the study.

The purpose of this article is to highlight conceptual approaches to the creation of theoretical model of the studies of verbal reconstruction of the system of symbols with the aim of studying the characteristics of coping with the condition of disadaptation.

\section{Construction of a theoretical model}

Considering different conceptual approaches to the construction of a theoretical model regarding the reconstruction of verbal symbols, we tried to take these scientific views as a basis, they convincingly reveal the role of symbols in the process of self-discovery and can be used for further research to overcome its condition of disadaptation.

So, Z. Freud's (Barden, 2012) approach to the reconstruction of characters in the framework of his psychoanalytic theory identified the reasons that underlie the emergence of certain psychological disorders. Z. Freud developed the first method in the history of psychotherapy, based on the verbal reconstruction of characters: the method of free association, analysis of derogations and interpretation.

Z. Freud (Barden, 2012) used two strategies for the verbal reconstruction of symbols by association, that the symbol and its value invoke, and also during the interpretation of the sign in the universal coordinate system. Thus, the strategy of working with symbol proposed by Freud are examined as a method of reconstruction of verbal symbols, which is based on the work of the word.

The psychoanalyst C. Jung (2007) believes that the symbol has two main functions: it implements the try to satisfy the frustrated instinctive impulse and turns the archetypal material. This vision of the symbol, in our opinion, reveals 
its extremely important function in the process of coping with the condition of disadaptation.

C. Jung (2007) applied the developed method of "active imagination" that involves working with the unconscious using the "view" of imaginary symbolic objects and their subsequent verbal reconstruction through dialogue and verbalization.

C. Jung (2007) defines active imagination as imaginary as activity (imaginative Tätigkeit): free of dreams, of phantasms, dreams in reality. The first stage of active imagination is a dream with open eyes that occurs spontaneously or is caused deliberately. The second stage in addition to passive contemplation of characters includes an assessment of what they mean. Proposed by K. Jung (2007), active imagination, is considered as a method giving the opportunity to dissect the features of the visual (work of imagination) and verbal (dialogue, interpretation, evaluation of sign) the reconstruction of the characters.

In the framework of the art therapy approach postulates a provision stating that in the product of human creativity reflects her repressed idea or emotion. Thus in the process of creative transformation of reality has the opportunity to reconsider its opinion or to transfer the emotion into the sphere of one's own conscious. During the reconstruction of the symbols of art is the link between what is already known and what is not yet understood.

The process of verbal reconstruction of symbols in art therapy provides a basis for understanding of unconscious information through the awareness of the importance of symbols. Verbal reconstruction of the personality symbols can occur in the process of finding answers to questions, or the application of the method of free Association, or the creation story, the tale on the symbolic interaction.

The use of counselor verbal reconstruction of symbols, including cultural and archetype strategy verbal interpretation allows not only to obtain additional content regarding the sign system of the client, but also helps to recreate the individual space of consciousness of the individual.

V. Oglander (Lebedeva, 2003, p. 25) gives the following rules for working with the verbal reconstruction of the author's drawing:

- to talk about his work as the author wants;

- part of the picture to comment on, explaining their significance;

- to describe certain forms, objects, characters;

- describe the work in the first person, it is desirable for each of the drawn elements;

- to build dialogue between different parts of the work, regardless of whether this is a symbolic representation of the geometric shape of the object, etc.; 
- it is necessary to distinguish between "ego - oriented" (for the author) and "object - oriented" (drawn character) questions and answers;

- if the author does not understand the meaning of the symbol, then we can give his explanation of symbolic content, but after this we need to ask the author how this explanation is perceived as "correct".

T. Yatsenko (2008) believes that using a psychodynamic interpretation of the drawings, which involves the intellectualization of images by the author, is the disclosure of relationships between his conscious and unconscious mind. The researcher uses the methodology of integral analysis of complex. T. Yatsenko (2008) noted the importance of the role of the characters, particularly the archetypal. The symbols shown in the drawings, can be considered "messengers" from unconscious to conscious, and their interpretation enriches the conscious. Concerning the meaning of the verbal process of reconstruction signs, etc. Yatsenko said that the figure is "dead" reflection of something living, functioning - a "fingerprint" need to do "talkative". This is the verbal reconstruction of a spontaneous story, the presentation of "the tales of your life"; treatment, questions to God, to fate, to himself.

V. Yakovlev (2006) emit, during operation, with the verbal reconstruction of the symbol "keyword" customer - words that have additional properties, which the psychologist finds in the customer's language. They stand out tonally, accompanied by facial expressions or gestures, pauses, unusual movements or "freezing" and "voltage" of the body; these are the words with atypical sounds and those that belong to other literary styles fall out of context. Such words are used during the "track draw".

"Words-the pressure" on the contrary, consciously stand out personality with the expectation of the external effect. These words are a projection of "key words", but they need transformation, it "masks" that hide the true meaning. Such "words", according to the scientist, can be used in the course of art therapy with the purpose underlying the treatment process, as they are the "key" for the further transformation of the personality. They can be used in the work with a symbol in addition to "figures of fantasy" (Yakovlev, 2006).

Actively used methods of reconstruction of symbols the founder of ontopsychology A. Meneghetti (2000). He was considered the symbol as a sign or image that indicates that some important aspect of human life (Meneghetti, 2000). The key to the symbolic content becomes verbal reconstruction of symbols in the process of working with the semantic field of personality.

According to the theory of A. Meneghetti (2000), to find the causes of the condition of disadaptation, to achieve internal integrity and self-identity it is important 
to find the right interpretation of the symbol. In the case where the person is not willing or not able to understand the causes of their own maladjustment, accompanied by interpreting the wrong characters, it is paying their health; losing way, which would give the chance to success [ibid]. In the process of verbal semantic reconstruction drawings, from our point of view, it is appropriate to appeal to the three criteria of interpretation of the symbols proposed by A. Meneghetti [ibid]:

- functionality of the nature of the object or context that is indicated by the symbol from the point of view of the person (i.e., what exactly this object means to the individual functional nature with respect to it);

- causal impact of character actions the character makes in relation to a person "here and now" (what's going on with him and what is his end result?);

- semantic criterion: the representation of the object in the relevant semantic field (i.e., in which direction the object is moving and to whom it is relevant? At the point of semantic space of the observed symbol and the targets of its action?).

Applying the three criteria at the same time, the person gets the key to the interpretation of symbols. The absence of even one of these criteria makes it impossible to fully interpret.

A. Meneghetti (2000) believed that the interpretation of the language of symbols that occurs during the verbal reconstruction using spontaneous drawing, allows us to determine the coordinates of the current potential to reveal a specific tendency and the need of the subject and avoid the contortion of its semantic space.

During the last years in Ukraine the growing popularity of the use of metaphoric associative cards (IAC) in psychotherapeutic work. If you are using MAC symbols is investigated on the basis of a ready metaphorical images by verbalization of certain plot (Kirsche, 2010). The application of the method of verbal Association of the reconstruction symbols is done by a special set of cards, allowing you to perform exercises during the combination of the framework with words and images.

For example, when the exercise "Double set" must implement the following procedure: to pull from the deck two cards-word and two cards-drawings. Received two card combinations are interpreted separately and then study their relationship. Verbal reconstruction of the symbol also occurs in such exercises as, for example, the task "Write a story", which involves pulling from a set of cards with two pictures and a story based on the images.

B. Dorst and G. Vogel (Dorst, Fogel, 2016, p. 64).there are five stages of work with the verbal reconstruction of characters, among which is noteworthy the study of the semantic field of the character using the record. 
The founder of emotionally-shaped therapy N. Linda (Linde, 2016, p. 6) mentions the possibility of work with the verbal reconstruction of the characters through their analysis. The use of "dialogue", what plays an important role during the analysis of the structure of psychological problems. For example: "Now imagine that image has a voice that he can tell...”

The therapist should also ask questions that help to reveal the hidden meaning of the symbol and calls it "Socratic dialogue with the image" (Linde, 2016, p. 129).

Questions can be as follows:

- What is the function of this image?

- What's he like?

- If you become it, what do you feel?

- On what part of the body does it affect?

- How does it affect you?

- What do I want to do with it?

- What do I want to tell him it?

- What is he thinking?

- What does he feel?

- How do you feel about him? etc.

Researchers N. Barden and T. Williams (Barden, 2012, p. 137) describe the technique of symbolic simulation, which is also tangent to the working with symbols and metaphor. The use of the personality metaphor as a means of verbal reconstruction, contains structural content of its experience.

There are the following characteristics of a metaphor:

- consists of symbols;

- used to express individual identity;

- helps to facilitate the description of experiences, particularly negative;

- may change and develop during the questions;

- creates a new experience;

- changing view of reality.

In his works of H. Leiner (1996) argues that symboldrama promotes the ability to experience, orientation and development of its identity in real life. H. Leiner (1996) stresses the importance of associative method. This method lies in the fact that free associations are transferred to the level of awareness, while deployed chain interpretation of the symbols, which are gradually directed to the resolution of the conflict.

In our view, a person in the state of maladjustment may not always be aware of areas of inconsistency of their own symbolic meanings. Identification and recover areas of these inconsistencies is possible in the case of the use, including verbal 
reconstruction of symbols. The reconstruction of the verbal complements and exzct symbolic meanings, helps to restore a realistic perception of reality. Therefore, the use of verbal reconstruction of the symbols, becomes the basis for expanding the field of awareness of the identity of the relevant situation; the basis for determining the factors contributing to the development of the state of maladjustment and reveals ways to overcome it.

Based on the above mentioned approaches to the reconstruction of verbal symbols, it can be argued that qualitative and meaningful work with a symbol, which promotes the formation of new meanings possible through an integrated approach using different methods of verbalization.

We have developed a research model of verbal reconstruction includes the following areas of work with symbolic content: the associative method, the interpretation of the content of character (for functional, efficient and semantic criteria), questions and answers, verbalization of a plot, working with archetype values, symbols, metaphors, key words search, the dialogue with the character.

The use of these areas provides the researcher the ability to obtain in working with symbols additional content (see figure 1).

\section{Conclusions}

So, the article highlights conceptual approaches to the construction of the theoretical model of the study of verbal reconstruction of the system of symbols: method of free Association. Freud's interpretation of symbol for functional, efficient and semantic value of A. Meneghetti; intellectualization drawing for T. Yatsenko; keywords according to V. Yakovlev and others.

The developed model of the study of verbal reconstruction of personal characters, containing a comprehensive approach to working with symbolic content, and includes the following areas: the associative method, question-answer, the verbalization of the story, work with archetype values, symbols, metaphors, key words search, provide the researcher the ability to receive additional content in the work with symbols.

Thus, the verbal reconstruction of the characters is one of the most important psychological tools, the use of which enables to move the symbolic meanings in the sphere of human consciousness, that is, the symbol in the process of its verbal reconstruction becomes personal values. 


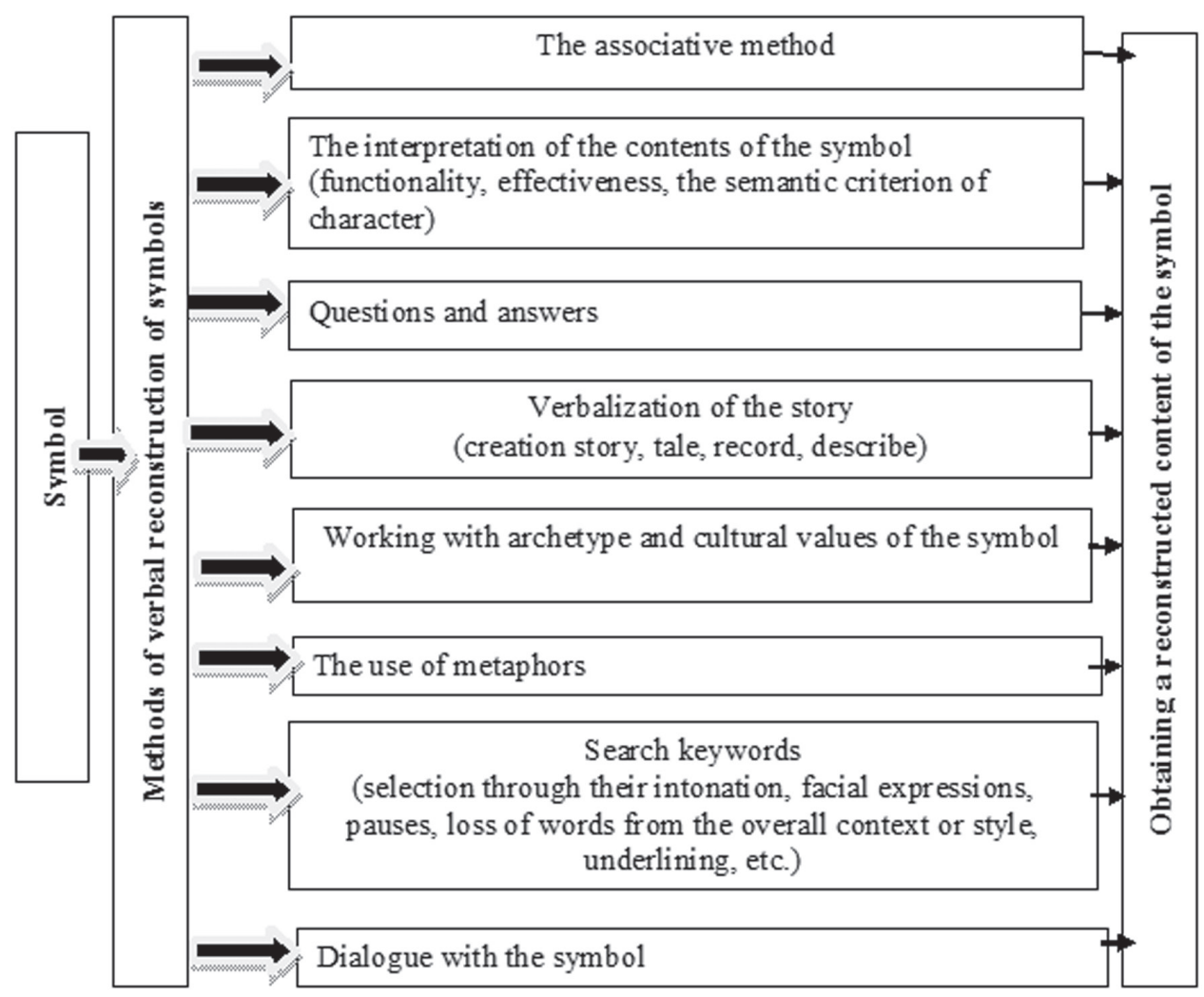

Fig. 1. Model studies of verbal reconstruction of personal characters Author: O. V. Lisoivan

Received 20161002 Approved for publishing 20161203

\section{Literature}

Barden, N. (2012). Words and symbols. Language and communication in therapy. Kharkiv: The Humanitarian Centre.

Dorst, B., Fogel, G. (2016). Active imagination. A Jungian approach. Kharkiv: Humanities Center.

Jungs, K. (2007). Analytical psychology: theory and practice. The Tavistock lectures. SPb.: Azbuka-Klassika.

Kirsche, V. (2010). Strawberries for window. Kharkiv: OH Verlag.

Lebedeva, L. (2003). The Practice of art therapy. SPb.: Speech.

Leiner, H. (1996). Catalinae experience images: Basic level. Introduction to psychotherapy, using the technique of dreams in reality. Seminar. Moscow: Eidos.

Linde, N. (2016). Emotionally-shaped therapy: the feeling-image-analysis-action. Moscow: Genesis.

Meneghetti, A. (2000). The Image and the unconscious: a Training manual in the interpretation of images and dreams. Moscow: NNBF Ontopsychology.

Yakovlev, V. (2006). Virtual worlds trance figure. Moscow: Independent firm "Class".

Yatsenko, T. S. (2008). Theory and practice of depth psychotherapy. Donetsk: DIEP. 